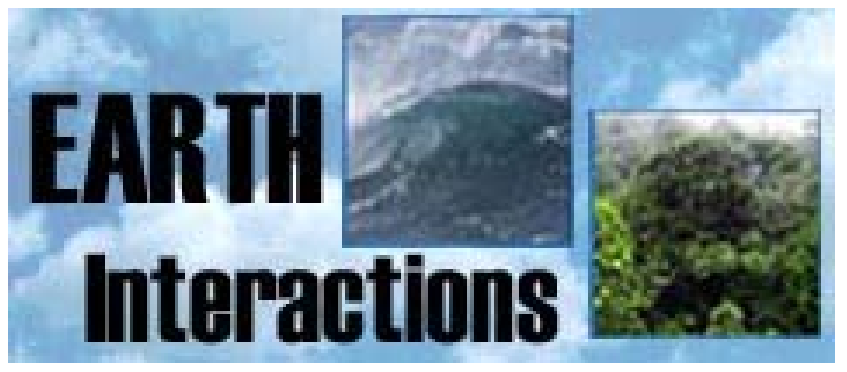

Copyright (C) 2004, Paper 8-013; 8,909 words, 10 Figures, 0 Animations, 4 Tables. http://EarthInteractions.org

\title{
Impacts of Climate Variation and Catchment Area on Water Balance and Lake Hydrologic Type in Groundwater-Dominated Systems: A Generic Lake Model
}

\section{Jeffrey Cardille*}

Department of Zoology, University of Wisconsin-Madison, Madison, Wisconsin

\section{Michael T. Coe and Julie A. Vano}

Center for Sustainablility and the Global Environment, University of WisconsinMadison, Madison, Wisconsin

Received 27 October 2003; accepted 16 January 2004

\begin{abstract}
Lakes are a major geologic feature in humid regions, and multiple lake hydrologic types exist with varying physical and chemical characteristics, connections among lakes, and relationships to the landscape. The authors developed a model of water fluxes through major components of groundwater-dominated lake catchments in a region containing thousands of lakes, the Northern Highland Lake District (NHLD) of northern Wisconsin and the Upper Peninsula of Michigan. The model was calibrated with data from widely differing lakes using the same set of simple equations to represent the hydrologic type, water residence time, and amount and timing of stream and groundwater flows of representative lakes in today's climate. The authors investigated the sensitivity of the water balance of a set of three connected
\end{abstract}

* Corresponding author address: Jeffrey Cardille, Department of Zoology, University of Wisconsin-Madison, Madison, WI 53706.

E-mail address: cardille@wisc.edu 
representative lakes and their catchments to systematic increases and decreases in the precipitation regime, and contrasted results using lake-specific morphometry to those for a lake having size and shape parameters typical of the region. Results indicate that a common set of equations can successfully represent major water balance characteristics of the three basic lake hydrologic types (hydraulically mounded, groundwater flowthrough, and drainage) in the NHLD. Sensitivity of modeled lakes varied by lake type, with drainage lakes more strongly buffered against substantial hydrologic changes in extreme climate scenarios. Catchment-scale water budgets differed substantially among lakes of different types, yet can be understood along a continuum of relative catchment size. These results suggest that a simple model of lake and catchment water balance can be extended to entire lake districts, where the detailed morphometry of most lakes is not well known.

KEYWORDS: Lake, Catchment, Groundwater

\section{Introduction}

Lakes are a major geologic feature in humid regions throughout the world. In groundwater-dominated systems, multiple lake hydrologic types exist with varying physical and chemical characteristics, connections among lakes, and relationships to the landscape. Hydraulically mounded lakes, those highest in the landscape, are connected to the groundwater system with a flow gradient sloping away from the lake in all directions (Kratz et al. 1997) and typically have only a small amount of surrounding catchment area; these lakes receive nearly their entire water budget from precipitation on the lake surface. Lower in the landscape, groundwater flowthrough lakes have groundwater flow into and out of the lake but no surface flow in or out. Drainage lakes, those lowest in landscape position, collect water by surface and groundwater flow from a relatively large catchment area and have flow out via groundwater and a stream for all or part of the year.

In lake-rich landscapes, attributes of the catchments surrounding lakes-such as the ratio of catchment area to lake area and flow paths to and from the lakeinfluence the quantity and composition of water entering and leaving the lake itself (Kratz et al. 1997; Webster et al. 1996; Webster et al. 2000). Physical properties of the lake and its catchment help determine 1) the hydrologic characteristics of the lake through effects on seasonality and interannual variability of the lake volume and surface height, sensitivity to drought, and water residence time; and 2) lake chemical and ecological properties, by impacting lake biogeochemistry, water clarity, organic and inorganic carbon content, carbonate and silicate concentration, nutrient loading, and biotic activity (Baines et al. 2000; Cole 1999; Gergel et al. 1999; Hurley et al. 1985; Kling et al. 2000; Riera et al. 2000; Soranno et al. 1999). For example, although lakes often show regionally similar long- and short-term variations in water quantity and quality as a result of climate variations (Harrison et al. 1996; Street and Grove 1976; Street-Perrott and Perrott 1993; Yu and Harrison 1995), there are often large dissimilarities among neighboring lakes that are due, in part, to the physical characteristics of the lake catchment (Dearing and Foster 1986; Magny 1992; Webster et al. 1996).

Understanding the dynamics of water and chemical flows among lakes in a 
complex landscape from observational data is, however, very difficult. Numerical models provide a means of understanding the links among the physical, hydrologic, and biogeochemical characteristics of a lake and its catchment. Although numerous hydrologic models exist for lakes (e.g., Hostetler et al. 1993; Vassiljev 1997), and many others exist for terrestrial ecosystems (e.g., Kucharik et al. 2000), few models are able to address the complexity of water dynamics on a lake-rich landscape of interconnected lake catchments. Such landscapes pose numerous problems, such as vastly different rates of water movement through ground and surface flows, changing morphometry of lakes as their volume rises or falls, and diverse hydraulic linkages among lakes dominated by rainwater, groundwater, or surface water inputs and outputs. This paper addresses such a region, the Northern Highland Lake District (NHLD) of northern Wisconsin and the Upper Peninsula of Michigan. In particular, we propose a simple, generalizable model that represents the hydrologic dynamics of diverse, interconnected lakes and catchments.

This study describes the development and application of a simple model to represent key water fluxes and components of the integrated land-lake system of the NHLD. The model is designed to include the fewest unique characteristics that can adequately and mechanistically simulate hydrologic characteristics - such as water residence time, volume, and groundwater and surface flow between lakesfor lakes of different sizes, shapes, and hydrologic types. The model developed here incorporates both streamflow and groundwater flow among nested lakes independent of landscape position, encoding simple relationships among morphometric parameters to capture the lake hydrologic type, water residence time, and amount and timing of stream and groundwater flows. The incorporation of water movement into and out of the surrounding terrestrial ecosystem allows the development of catchment-scale water budgets, which track the fate of all water falling within the entire groundwater catchment, in addition to the more common accounting of lake water budgets. With the model validated in representative lakes from the NHLD, we address the following questions.

1. In the NHLD, what is the relative effect of lake hydrologic type and climate on water balance measures?

2. What factors most strongly influence lake type and the fate of precipitation in groundwater-dominated catchments of the Northern Highlands?

Through exploration of lake responses with this model, we can begin to conceptualize the interactions between terrestrial and aquatic ecosystems in this complex landscape.

\section{Study region}

The NHLD of northeastern Wisconsin and western Upper Michigan (Figure 1) is a formerly glaciated landscape characterized by complex hummocky terrain with a diverse mix of lakes, wetlands, and vegetated uplands. With more than 2500 lakes in an area of about $3500 \mathrm{~km}^{2}$ (Riera et al. 2000), the lakes cover about $11 \%$ of the landscape while wetlands cover another $25 \%$. Forested uplands and shrubland make up the remainder of the region. 

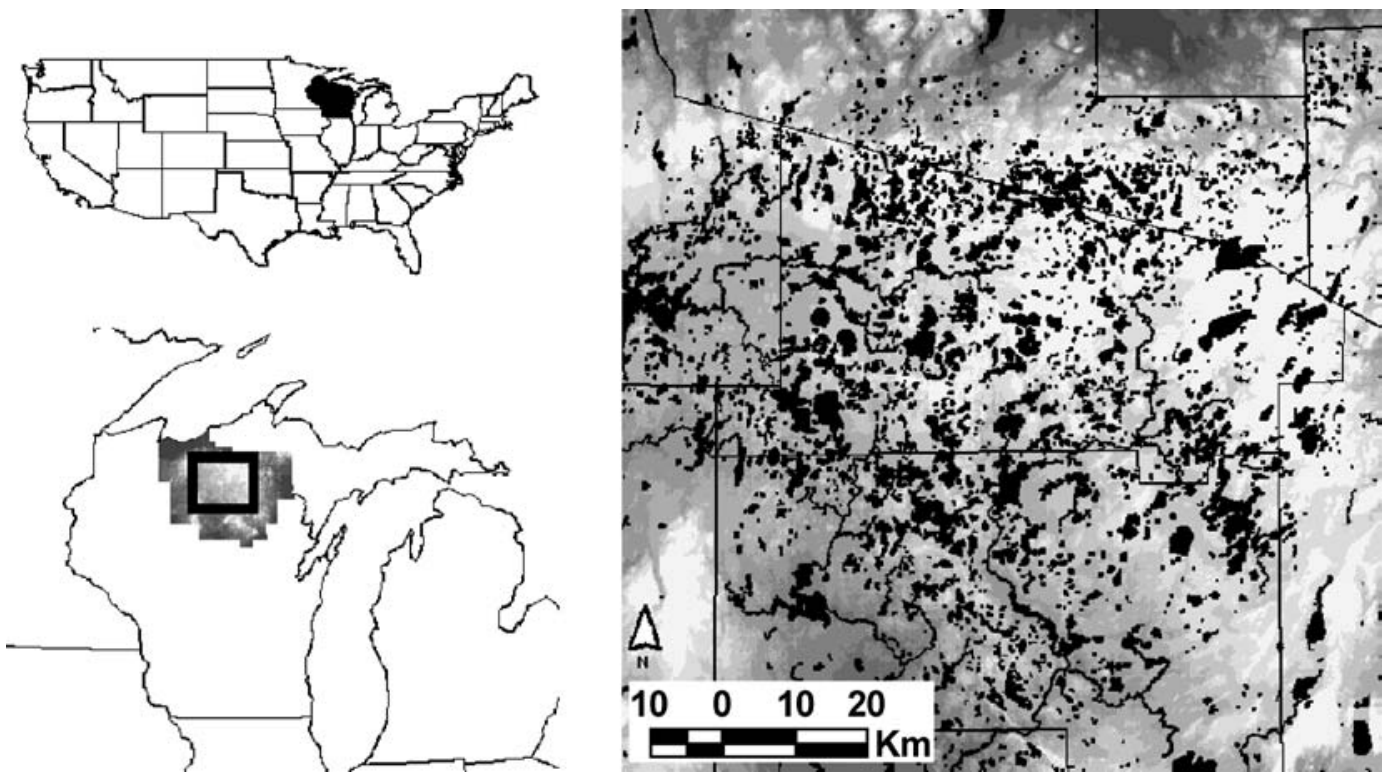

Figure 1. Lakes and location of the NHLD.

The physical and chemical characteristics of lakes in the NHLD are extremely heterogeneous, with lake size, shape, density (Benson and Mackenzie 1995; Bureau of Water Resources Management and Bureau of Fisheries Management 2001), clarity (Chipman et al. 2004), and chemistry (Riera et al. 2000) varying substantially at multiple scales throughout the district. Hydrological and chemical connections among lakes and the ratio of lake area to catchment area also vary greatly (Benson et al. 2000; Bullen et al. 1996; Kim et al. 1999).

The physical, chemical, and ecological characteristics of some individual lakes in the NHLD have been studied extensively (e.g., Magnuson et al. 2004). Driven by the key concept of landscape position (Kratz et al. 1997), recent research has focused on describing and understanding the variability of lakes across the district. For example, Baines et al. (Baines et al. 2000) and Soranno et al. (Soranno et al. 1999) showed that similarity in landscape position largely determines the similarity of the physical and chemical properties of pairs of lakes in the NHLD, and Riera et al. (Riera et al. 2000) linked landscape position to chlorophyll concentration, crayfish abundance, and fish richness. Further studies in the NHLD show that whether or not water flows through a wetland strongly influences methyl mercury cycling (Krabbenhoft et al. 1995) and the dissolved organic carbon content of lakes and streams (Elder et al. 2000; Gergel et al. 1999).

Modeling of water transport in this region has added greatly to the understanding of lake ecosystems, complementing results gleaned from field research. For example, Hunt et al. (Hunt et al. 1998) and Walker and Krabbenhoft (Walker and Krabbenhoft 1998) developed and applied an analytic-element groundwater transport model for the Trout Lake catchment, a small but closely examined part of the NHLD. These studies illustrate the complexity of the physical and temporal characteristics of subsurface water flow in this region and therefore the importance 


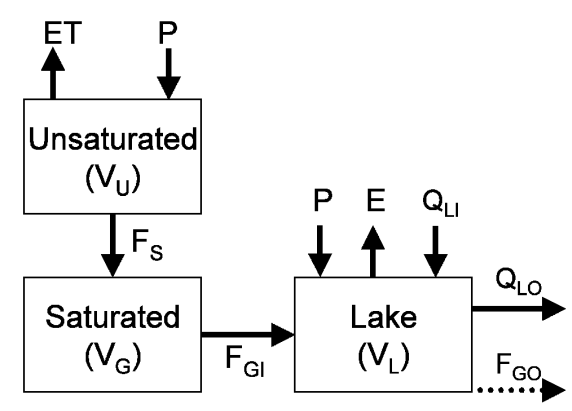

Figure 2. Conceptual model of water movement through lake catchments in groundwater-dominated systems.

of understanding the flow path of water through a lake catchment. More recently, Dripps (Dripps 2003) coupled a mechanistic land surface model to an analyticelement groundwater transport model of the Trout Lake region to show that in addition to flow path, vegetation type is an important determinant of the recharge to the groundwater system and catchment water budgets in this region.

\section{Methods}

\subsection{Model structure}

\subsubsection{Conceptual model of catchment-scale water balance in the NHLD}

In this study, we developed a model of dynamic water balance for a lake and its groundwater catchment as being driven by water movement through three reservoirs: the unsaturated zone, the saturated zone, and the lake (Figure 2). This prototype model is designed to be applied to a very large number of interconnected lakes for which little is known about morphometric characteristics, surface flow, or subsurface connections. The spatial extent of a given model implementation is a lake's groundwater catchment, since with very little overland flow due to high infiltration, subsurface divisions more strongly influence lake water budgets (Elder et al. 2000). Driven by monthly climate data and with a daily time step, the model represents the reservoir volumes and flows among them as described below.

\subsubsection{Unsaturated zone: Inputs and outputs}

The volume of water in the unsaturated zone of a catchment $\left(V_{U}, \mathrm{~m}^{3}\right)$ is modeled as the sum of the volume of water in the unsaturated zone in the previous time step, precipitation $\left(P, \mathrm{~m} \mathrm{day}^{-1}\right)$ minus evapotranspiration $\left(\mathrm{ET}, \mathrm{m} \mathrm{day}^{-1}\right)$ infiltrated from the land surface area $\left(\mathrm{LD}, \mathrm{m}^{2}\right)$, and flux $\left(F_{S}, \mathrm{~m}^{3} \mathrm{day}^{-1}\right)$ from the unsaturated to the saturated zone. At each time step $t$, the amount of water in the unsaturated zone of the lake catchment is governed by the following differential equation:

$$
V_{U}(t)=V_{U}(t-d t)+\left[(P-\mathrm{ET}) \mathrm{LD}-F_{S}\right] d t .
$$

The flux $\left(F_{S}\right)$ from the unsaturated zone routes water is greater than the soil's holding capacity to the groundwater pool and is a function of a residence time constant in the unsaturated zone reservoir $\left(c_{1}\right.$, day $\left.{ }^{-1}\right)$, the current volume of 
water in the unsaturated zone $\left(V_{U}\right)$, and the estimated maximum water-holding capacity of the unsaturated zone $\left(V_{\mathrm{Ur}}, \mathrm{m}^{3}\right)$. The $V_{\mathrm{Ur}}$ was estimated to be linearly related to the upland area of the catchment as $10 \mathrm{LD}$. The flux is represented by a simplification of the Manning streamflow equation and is similar to equations used in simple flow models (e.g., Coe 1998; Miller et al. 1994) as the following:

$$
F_{S}=\max \left\{c_{1}\left(V_{U}-V_{\mathrm{Ur}}\right)\left[\left(V_{U}-V_{\mathrm{Ur}}\right) / V_{\mathrm{Ur}}\right]^{1 / 2}, 0\right\} \text {. }
$$

\subsubsection{Saturated zone: Inputs and outputs}

The volume of water in the saturated zone or groundwater pool of a lake catchment $\left(V_{G}, \mathrm{~m}^{3}\right)$ is modeled in the same manner as in the unsaturated zone: as a function of the sum of the volume in the saturated zone in the previous time step, the flux from the unsaturated zone $\left(F_{S}\right)$, and the flux from the saturated zone to the lake $\left(F_{\mathrm{GI}}, \mathrm{m}^{3}\right.$ day $^{-1}$ ). At each time step $t$, the amount of water in the saturated zone $V_{G}$ of the lake groundwater catchment is governed by the following differential equation:

$$
V_{G}(t)=V_{G}(t-d t)+\left(F_{S}-F_{\mathrm{GI}}\right) d t .
$$

The flux $\left(F_{\mathrm{GI}}\right)$ from the saturated zone to the lake routes water is greater than the groundwater pool capacity into the lake and is a function of the water residence time $\left(c_{2}\right.$, day $\left.{ }^{-1}\right)$, the current volume of water in the groundwater pool $\left(V_{G}\right)$, and the estimated maximum volume of the saturated zone $\left(V_{\mathrm{Gr}}, \mathrm{m}^{3}\right)$. The $V_{\mathrm{Gr}}$ was estimated to be linearly related to the upland area of the catchment as $10^{4} \mathrm{LD}$. Flow from the groundwater pool to the lake, $F_{\mathrm{GI}}$, is represented by the following equation:

$$
F_{\mathrm{GI}}=\max \left\{c_{2}\left(V_{G}-V_{\mathrm{Gr}}\right)\left[\left(V_{G}-V_{\mathrm{Gr}}\right) / V_{\mathrm{Gr}}\right]^{1 / 2}, 0\right\} .
$$

Together the $c_{i}$ values and reference volumes created a pair of subsurface pools with differing residence times and effective velocities. Since we did not know the actual soil and groundwater pool volumes, our goal was to select parameters that provided a reasonable seasonal cycle, as described below. This created a relatively fast pool in the unsaturated zone, with little capacity and fast flushing, and a larger and much slower pool in the saturated zone.

\subsubsection{Lake: Inputs and outputs}

The volume of water in the lake $\left(V_{L}, \mathrm{~m}^{3}\right)$ is modeled as the sum of the lake volume in the previous time step, the precipitation $(P)$ minus the evaporation $(E$, $\mathrm{m} \mathrm{day}^{-1}$ ) from the lake surface $\left(\mathrm{LA}, \mathrm{m}^{2}\right)$, the flux from the saturated zone to the lake $\left(F_{\mathrm{GI}}\right)$, stream inflow $\left(Q_{\mathrm{LI}}\right)$ from upstream lakes, the flux $\left(F_{\mathrm{GO}}\right)$ from the lake to the saturated zone (groundwater pool), and the stream outflow $\left(Q_{\mathrm{LO}}\right)$, if any, from the lake (all fluxes are in $\mathrm{m}^{3} \mathrm{day}^{-1}$ ). At each time step $t$, the volume of water in the lake $V_{L}$ is governed by the following differential equation:

$$
V_{L}(t)=V_{L}(t-d t)+\left[(P-E) \mathrm{LA}+F_{\mathrm{GI}}+Q_{\mathrm{LI}}-F_{\mathrm{GO}}-Q_{\mathrm{LO}}\right] d t .
$$

Groundwater seepage from the lake, $F_{\mathrm{GO}}$, occurs at a rate proportional to the conducting lake bed area $B\left(\mathrm{~m}^{2}\right.$, described in a later section). In this region, ice 
Table 1. Morphometric and catchment characteristics for three representative lakes in the NHLD.

\begin{tabular}{|c|c|c|c|c|c|c|}
\hline & \multicolumn{2}{|c|}{ Crystal } & \multicolumn{2}{|c|}{ Big Muskellunge } & \multicolumn{2}{|c|}{ Allequash-North Basin } \\
\hline & Value & Source & Value & Source & Value & Source \\
\hline Surface Area (ha) & 37 & $\mathrm{a}$ & 363 & $\mathrm{a}$ & 112 & $\mathrm{~b}$ \\
\hline Mean Depth (m) & 10.4 & $\mathrm{c}$ & 7.5 & $\mathrm{c}$ & 3.8 & $\mathrm{c}$ \\
\hline Max Depth (m) & 20.4 & $\mathrm{c}$ & 21.3 & $\mathrm{c}$ & 8 & $\mathrm{c}$ \\
\hline Volume $\left(\mathrm{m}^{3}\right)$ & $3.8 \mathrm{E}+06$ & $\mathrm{~g}$ & $2.7 \mathrm{E}+07$ & $\mathrm{~g}$ & $4.3 \mathrm{E}+06$ & $\mathrm{~g}$ \\
\hline Conducting lake bed area (ha) & 1.73 & $\mathrm{~d}$ & 31.49 & $\mathrm{~d}$ & 15.84 & $\mathrm{~d}$ \\
\hline Catchment extra area (ha) & 4 & $\mathrm{e}$ & 140 & $\mathrm{e}$ & 2857 & $\mathrm{f}$ \\
\hline Total catchment area & 41 & $\mathrm{~h}$ & 544 & $\mathrm{~h}$ & 3513 & $\mathrm{~h}$ \\
\hline $\begin{array}{l}\text { Catchment area: total lake } \\
\text { area }\end{array}$ & 1.11 & $\mathrm{~h}$ & 1.36 & $\mathrm{~h}$ & 6.86 & $\mathrm{~h}$ \\
\hline
\end{tabular}

Sources:

${ }^{a}$ Wisconsin DNR wihydro coverage.

${ }^{\mathrm{b}}$ LTER lake morphometric data, lter.limnology.wisc.edu.

${ }^{\text {c }}$ Webster et al. (1996).

${ }^{\mathrm{d}}$ Computed via morphometry equations.

${ }^{\mathrm{e}}$ Chosen to roughly match GW input rate from Webster.

${ }^{\mathrm{f}}$ Elder et al. (2000).

${ }^{g}$ Multiplication of mean depth * surface area.

${ }^{\mathrm{h}}$ Computed from values in table.

scour limits lake sedimentation in the upper $1 \mathrm{~m}$ of the lake; this corresponded to about $10 \%$ of the lake's total volume. When $V_{L}$ is above $90 \%$ of the lake's maximum volume, groundwater seepage from the lake is modeled as a function of a constant $\left(c_{3}, \mathrm{~m} \mathrm{day}^{-1}\right)$ and $B$ as the following:

$$
F_{\mathrm{GO}}=c_{3} B \text {. }
$$

Stream outflow $\left(Q_{\mathrm{LO}}\right)$ occurs when the simulated lake volume exceeds its maximum. The potential maximum volume that a given lake can attain before stream outflow occurs to the next downstream lake is known for only a few wellstudied lakes in the NHLD. For this model, the surface area multiplied by mean depth (i.e., the volume from Table 1) was used as the reference volume $\left(V_{\mathrm{Lr}}, \mathrm{m}^{3}\right)$; when the volume of water in the lake pool was larger than $V_{\mathrm{Lr}}$, the lake's banks were breached and streamflow resulted to the next downstream lake. Stream outflow is simulated as a function of a time constant $\left(c_{4}\right.$, day $\left.{ }^{-1}\right)$ and the water in excess of the reference volume using the following equation:

$$
Q_{\mathrm{LO}}=\max \left\{c_{4}\left(V_{L}-V_{\mathrm{Lr}}\right)\left[\left(V_{L}-V_{\mathrm{Lr}}\right) / V_{\mathrm{Lr}}\right]^{1 / 2}, 0\right\} .
$$

\subsection{Driving data}

\subsubsection{Precipitation}

Mean monthly precipitation from the CRU05 dataset (New et al. 2000) for the period 1992-96, centered over the NHLD ( $46.25^{\circ}$ latitude, $-89.75^{\circ}$ longitude) is used to drive the model (Figure 3). The model does not explicitly simulate the freezing and thawing of lakes; instead, similar to Champion (Champion 1998), precipitation falling between 15 November and 15 March (when mean temperature 


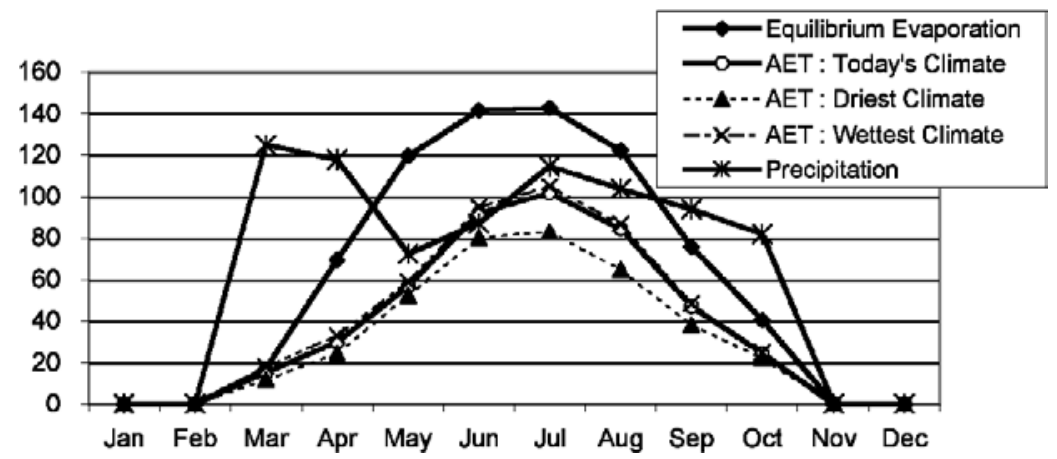

Figure 3. Modeled precipitation, equilibrium evaporation, and evapotranspiration $(\mathrm{mm})$ in the NHLD.

is below $0^{\circ} \mathrm{C}$ ) is stored as snowfall evenly throughout the catchment. In spring, two-thirds of the winter's snowfall infiltrates (or, for winter precipitation over the lake, enters the lake directly) in the latter half of March and the remaining one-third in April. The resulting distribution of the annual mean of $795 \mathrm{~mm}$ of liquid precipitation has a maximum in March and April and a second peak in July (Figure $3)$.

\subsubsection{Equilibrium evaporation and evapotranspiration}

The mean monthly lake evaporation and evapotranspiration required as input to the lake catchment model are calculated from the mean monthly CRU05 data for the region. Equilibrium evaporation from lakes in the NHLD is calculated using a simple Penman-Monteith model with Priestley-Taylor correction as by Coe (Coe 1998). Actual evapotranspiration (AET) is calculated using the Integrated Biosphere Simulator (IBIS) land surface model (Foley et al. 1996; Kucharik et al. 2000) for the temperate deciduous forest vegetation type on a loamy sand soil. Because IBIS is not tuned for the NHLD, the annual simulated AET was adjusted to correspond to the observed annual amount of stream outflow recorded from Allequash Lake for 1992-96. This adjustment increased IBIS AET results by about $7 \%$ in each month. The resulting AET as a proportion of precipitation (0.57) is within the range of estimates commonly used for this region. During the winter months, the small E and AET estimates are set to zero for consistency with precipitation settings (Figure 3).

\subsubsection{Catchment-scale water balance}

Hydrologic budgets of nearby catchments can vary (e.g., Likens 1985). Here, the model-integrating aquatic and terrestrial processes across multiple catchments allows the calculation of a catchment-scale water balance depicting the relative amount of groundwater seepage, evapotranspiration, lake evaporation, and outflow occurring in a modeled catchment. Given the values of $P, E$, and ET and the assumption of a homogeneous substrate throughout a given lake's catchment, the equilibrium water balance for the entire catchment can be represented as the sum of 


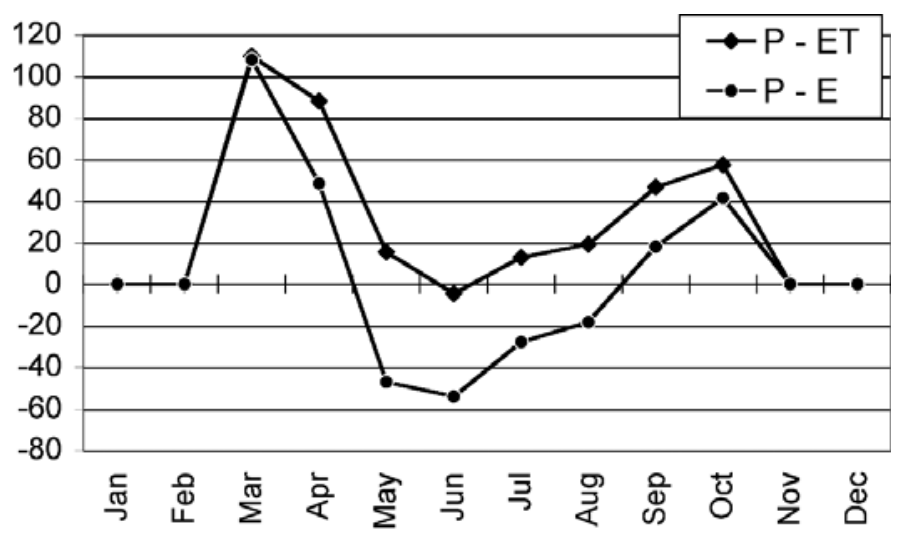

Figure 4. The NHLD 1992-96 monthly means $P$ - E and $P$ - ET (mm).

the water balance from the terrestrial area (LD) of the catchment and that of the lake surface area (LA). In groundwater systems, outputs from a catchment occur through groundwater flow from the lake $\left(F_{\mathrm{GO}}\right)$ and overland flow $\left(Q_{\mathrm{LO}}\right)$, and balance inputs such that

$$
F_{\mathrm{GO}}+Q_{\mathrm{LO}}=\mathrm{LD}(P-\mathrm{ET})+\mathrm{LA}(P-E) .
$$

Thus, mounded lakes surrounded by relatively little upland (where LD is small relative to LA) have a catchment-scale water balance more strongly driven by evaporation than by evapotranspiration; conversely, catchments with a large land area relative to lake area reflect a water balance more closely linked to the value of precipitation minus evapotranspiration. A given lake's water budget is driven by a weighted combination of these two curves (Figure 4).

\subsection{Lake morphometry}

Lake morphometry influences lake water balance by affecting the evaporating surface area for a given lake volume and the portion of the lake bed that transmits groundwater flow in and out of the lake. In scenarios where lake volume changes substantially, lake morphometry influences the remaining lake surface area, changing the amount of evaporation from the lake surface and thereby potentially influencing the lake water budget. Bathymetric information to provide detailed lake shape data, however, is relatively rare among the district's many lakes; therefore, we estimated the relationship between lake volume and lake surface area at multiple depths for lakes in the region using the detailed bathymetry available for five lakes from the Long-Term Ecological Research (LTER) program (Benson 2003). This relationship (Figure 5), derived for lakes of substantially different sizes and shapes, was approximated well by a simple geometric approach:

$$
\mathrm{LA}(t)=\operatorname{LA}_{r}\left(V_{L} / V_{\mathrm{Lr}}\right)^{(2 / 3)},
$$

where $\mathrm{LA}_{r}$ is the reference surface area for the given lake.

In lakes of the Northern Highlands, fine sediments in deeper water limit groundwater conduction to only the shallowest depths (Winter et al. 1998). This 


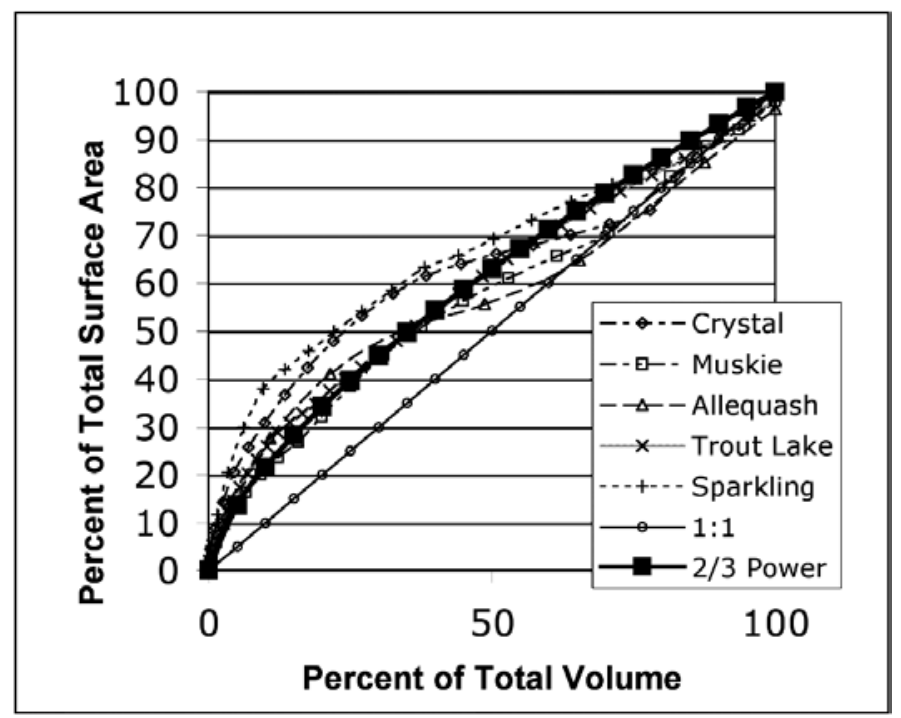

Figure 5. Relative surface area vs relative volume in LTER lakes.

conducting area can vary widely depending on lake size and shape; this is particularly important for mounded and groundwater flowthrough lakes, for which groundwater flow (along with lake evaporation) is the only path for water to leave the lake. We assumed that groundwater conduction was limited to sediments in water shallower than $1 \mathrm{~m}$, consistent with more detailed studies (Christensen et al. 1996). This conducting lake bed area B was estimated for three reference lakes (Table 1) using morphometric equations following Carpenter (Carpenter 1983). A comparison of bathymetry for LTER lakes indicated that this top $1 \mathrm{~m}$ of lake volume corresponded to about $10 \%$ of the lake's total volume. Therefore, in our model, when the simulated lake volume drops below $90 \%$ of the reference volume, groundwater flux from the lake is set to zero.

\subsection{Representative mounded, groundwater flowthrough, and drainage lakes}

The lake water balance model was calibrated in three well-studied lakes representing a wide range of characteristics in the NHLD (Table 1). Crystal Lake, a small hydraulically mounded lake, has a budget dominated by precipitation inputs, with little groundwater flow into the lake. Big Muskellunge, the representative groundwater flowthrough lake, is an order of magnitude larger in surface area but has nearly the same depth as Crystal Lake. The north basin of Allequash Lake is shallower but with more surface area than Crystal Lake, containing about the same amount of water but surrounded by a substantially larger catchment. Though the actual connections among these lakes are complex (Pint 2002), we approximated their relationships by modeling Crystal Lake's catchment as being contained within Big Muskellunge's catchment, and Big Muskellunge's catchment nested within that of Allequash. This relatively simple flow path corresponded with the level of detail available for other lake systems across the 
entire NHLD, where the connections among groundwater catchments are much less understood.

\subsection{Experiments}

The nested model was run with repeating climate data using monthly averages from the period 1992-96 using a daily time step for 490 months, by which point all flows and stocks had reached equilibrium. The model was tuned using today's climate by adjustments to values of the residence time constants $c_{1}, \ldots, c_{4}$ in order to simultaneously 1) ensure the correct hydrologic lake type (hydraulically mounded, groundwater flowthrough, or drainage) for each reference lake, 2) produce a modeled steady-state lake volume near the observed value, and 3) produce an outflow amount matching observations for the drainage lake. With the tuned model we performed two experiments. First, to explore the sensitivity of lake types in the model to changing climate drivers, we systematically varied precipitation inputs to the lake systems. Second, to explore the effect of catchment size on the catchment-scale water balance in lakes of different types, we analyzed simulations that varied the catchment area surrounding a lake of typical size and shape in the NHLD.

\subsubsection{Effect of climate drivers}

We systematically varied the precipitation and AET regime in the three lakes to explore the effect of lake hydrologic type and climate on water balance measures. Monthly precipitation means for 1992-96 were multiplied by a factor of $0.5,0.6$, $0.7,0.8,0.9,1.1,1.2,1.3,1.4$, and 1.5 to form 10 new simple precipitation scenarios. For each precipitation scenario, we used IBIS to estimate the amount of AET for the given vegetation type (Figure 3). As with the nominal case, IBIS was used to calculate the mean monthly AET for each precipitation scenario.

\subsubsection{Effect of relative catchment area}

Because the effect of catchment area has been seen to be important in understanding the water balance of sealed lakes (Vassiljev 1997), we explored the effects of systematically varying the size of the groundwater catchment surrounding a lake of median size and shape in the groundwater-dominated NHLD. For these runs, the lakes of Vilas and Oneida Counties, which contain the majority of the lakes in the NHLD, were investigated to determine the median lake area and mean depth among the 186 lakes with both of these values recorded (Bureau of Water Resources Management and Bureau of Fisheries Management 2001). Using these criteria, a typical lake from Vilas and Oneida Counties has a maximum depth of $9.14 \mathrm{~m}$, a mean depth of $3.96 \mathrm{~m}$, and a surface area of 109 ha (and thus a volume of $4.3 \mathrm{E}+06 \mathrm{~m}^{3}$ ). The typical lake's depth ratio (mean depth/maximum depth) was 0.43 , a common value in glacial terrain (Wetzel 2001).

To develop an understanding of the influences of lake type in groundwater-fed systems, we simulated the typical lake while systematically varying the ratio of lake area to catchment. For these simulations, sufficient land was added surrounding the lake area to create a ratio between the catchment area and lake 
Table 2. Major water balance characteristics of basic lake types in the NHLD.

\begin{tabular}{lcccccc}
\hline & & & & Reference \\
& $\begin{array}{c}\text { Reference } \\
\text { volume }^{\mathrm{a}}\end{array}$ & $\begin{array}{c}\text { Mean } \\
\text { modeled } \\
\text { volume }\end{array}$ & $\begin{array}{c}\text { Reference } \\
\text { WRT }^{\mathrm{b}}(\mathrm{yr})\end{array}$ & $\begin{array}{c}\text { Modeled } \\
\text { modeled } \\
\text { WRT (yr) }\end{array}$ & $\begin{array}{c}\text { GW\% } \\
\text { input to } \\
\text { lake }^{\mathrm{b}}\end{array}$ & $\begin{array}{c}\text { input to } \\
\text { lake }\end{array}$ \\
\hline Crystal (Mounded) & $3.8 \mathrm{E}+06$ & $3.7 \mathrm{E}+06$ & 12.7 & 11.9 & 6 & 6 \\
Big Muskellunge (Seepage) & $2.7 \mathrm{E}+07$ & $2.6 \mathrm{E}+07$ & 8.0 & 8.1 & 16 & 16 \\
Allequash (Drainage) & $4.3 \mathrm{E}+06$ & $4.5 \mathrm{E}+06$ & 0.5 & 0.4 & 31 & 92 \\
\hline
\end{tabular}

a See Table 1 for derivation.

b Webster et al. (1996).

area of 30:1, 15:1, 10:1, 5:1, 3:1, 2.5:1, 2:1, 1.5:1, 1.25:1, and 1:1 (i.e., no upland catchment).

\section{Results}

\subsection{Basic results by lake hydrologic type}

\subsubsection{Volume, water residence time, and groundwater input}

Results suggest that a common set of equations can successfully represent major water balance characteristics of the three basic lake types in the NHLD (Table 2). In all three representative lakes, equilibrium values for volume and water residence time (WRT) from the steady-state runs were within $10 \%$ of observed values, with the exception of water residence time for Allequash Lake. That slightly larger discrepancy may have been primarily due to the WRT estimation method used by Webster et al. (Webster et al. 1996), which divided the volume by the observed outflow since a detailed water budget for that lake was unavailable. Using the equation employed by Webster et al., modeled WRT was $0.44 \mathrm{yr}, 88 \%$ of their estimate of $0.5 \mathrm{yr}$. Taken as a whole, modeled estimates of volume and WRT across lake types agreed well with observed values.

The proportion of the lake budget accounted for by groundwater input differed dramatically across lakes. Because the amount of upland surrounding Crystal and Big Muskellunge was chosen for the model to approximate the observed groundwater input proportion, modeled and observed values agree (Table 2). For Allequash Lake the difference between modeled and observed groundwater input as a proportion of the lake balance, however, differs substantially, and the difference illustrates the simplification of the land surface in the Allequash catchment. Lacking a hydrologic budget for Allequash Lake, Webster et al. (Webster et al. 1996) extrapolated cation data to estimate its proportion of groundwater input, using data from nearby lakes with lower groundwater inputs. The model described here, in contrast, directly estimates the water budget for the lake, indicating that $89 \%$ of the input to Allequash Lake originates as precipitation falling on land rather than the lake surface. Included in the model's groundwater flow to the lake is the water delivered in reality from Allequash Springs, where the water table intersects with the surface to form a groundwater-fed creek that enters Allequash Lake. In this model, in contrast, all water entering the lake (except through precipitation directly on the lake surface) was categorized as flow from the 
Table 3. Modeled catchment-scale water balance proportions for three representative lakes in the NHLD.

\begin{tabular}{lccc}
\hline & Crystal & Big Muskellunge & Allequash \\
\hline Evaporation & 0.80 & 0.66 & 0.13 \\
Groundwater flux from lake & 0.13 & 0.18 & 0.01 \\
Outflow & - & - & 0.36 \\
Evapotranspiration & 0.07 & 0.16 & 0.48 \\
\hline
\end{tabular}

saturated zone, since it does enter the groundwater pool after entering the catchment. Therefore, the differences in estimates of relative groundwater inputs are likely due to the complex flow path of water transported to the lake and the simplifications in the model assumptions, the terrain representation, and the extrapolation method in Webster et al. (Webster et al. 1996).

\subsubsection{Lake and catchment-scale water budgets}

The fate of water falling within each modeled catchment differed substantially among the three lake types at equilibrium (Table 3). Evapotranspiration was the largest flux of water from the entire Allequash catchment, composing $48 \%$ of the water budget. Crystal and Big Muskellunge, in contrast, had ET terms that were much smaller-only about $10 \%-20 \%$ of the landscape's water budget. In these lakes, with catchment sizes that were much smaller relative to lake size (Table 1), water flux from the entire landscape was instead dominated by evaporation from the lake surface: $80 \%$ in Crystal and 66\% in Muskellunge.

\subsubsection{Lake hydrologic type}

In addition to correctly modeling the volume and WRT for the three lakes, the model correctly represented the lake type of each using the same set of calibration parameters. Crystal Lake, mounded in the landscape, receives groundwater from only its small immediate catchment; apart from a small ET term and the large amount of evaporation from the lake surface, its volume was maintained through flux from the groundwater-conducting lake bed to the saturated zone, with no stream outflow (Table 3). Modeled with the same groundwater flux rate from its lake bed as in Crystal, Big Muskellunge maintained its volume by loss to groundwater. With no stream outflow, it was correctly represented as a groundwater flowthrough lake.

Allequash Lake was correctly represented as a drainage lake, and both the amount and timing of the outflow agreed with observed results. Because the adjustment of modeled ET was driven in part to match the total annual outflow amount from Allequash, it was not surprising that the annual totals between modeled and observed outflow were nearly the same, with about $850000 \mathrm{~m}^{3}$ for each. Though the simulations were tuned only to agree with the annual mean outflow from Allequash Lake, the seasonal timing of flow also agreed very well with observed stream gauge data for Allequash Creek (Figure 6). Modeled monthly outflow was within one standard error of the monthly flow between 1992 and 1996 at Allequash Creek in all nonwinter months (Figure 6). Modeled outflow was highest in April and May, as melting winter snows increased lake level; there was a 


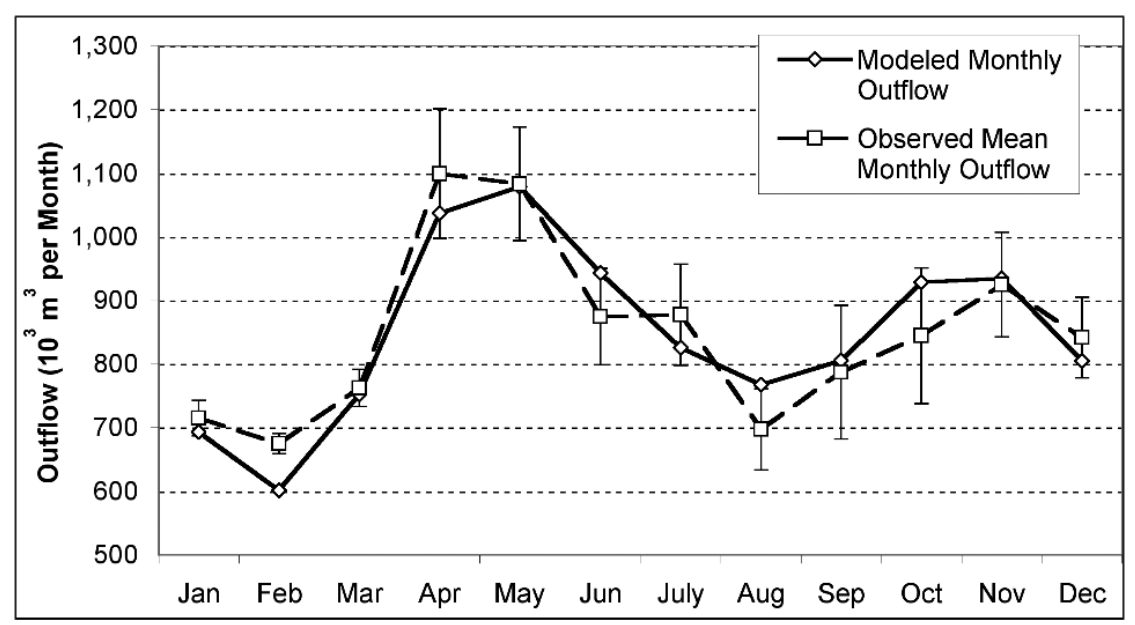

Figure 6. Stream outflow, Allequash Lake: monthly observed (1992-96 monthly means) and modeled values.

second peak in late autumn when ET dropped (Figure 3, Figure 4) with precipitation still relatively high. Although slightly outside the standard error bars, simulation of the first two months of the year captured the low outflow of that season without explicitly simulating the freezing and thawing of the lake surface. Given that the same parameter settings successfully modeled lake type and WRT while simultaneously maintaining lake volume in Crystal and Big Muskellunge with no stream outflow, the hydrograph of discharge from Allequash Lake captured the amount of timing of flow quite well.

\subsection{Sensitivity to precipitation changes}

With the water balance model having successfully simulated basic lake parameters for today's climate, we varied the precipitation input to the system to explore its effect across lake types. The effects of the precipitation changes were analyzed with respect to lake volume and water residence times, as were the catchment-scale water balance measures for each lake type.

\subsubsection{Lake volume and water residence time}

In scenarios of increased precipitation, each of the three lake types reached and maintained its modeled maximum volume (Figure 7 top), as excess water above the modeled maximum was routed from the system as stream outflow. In scenarios of decreased precipitation, the impact of climate on lake volume varied by lake type. In Crystal and Big Muskellunge Lakes, with small catchments relative to their respective lake areas, scenarios of decreased precipitation had stronger effects on steady-state lake volume than in Allequash (Figure 7 top). With a landscape water budget driven primarily by the difference between precipitation and evaporation from the lake surface, Crystal was the lake most susceptible to diminished volume in scenarios of drier climates; its volume began to decline substantially in the scenario driven using $90 \%$ of today's precipitation. Because it had a slightly larger 

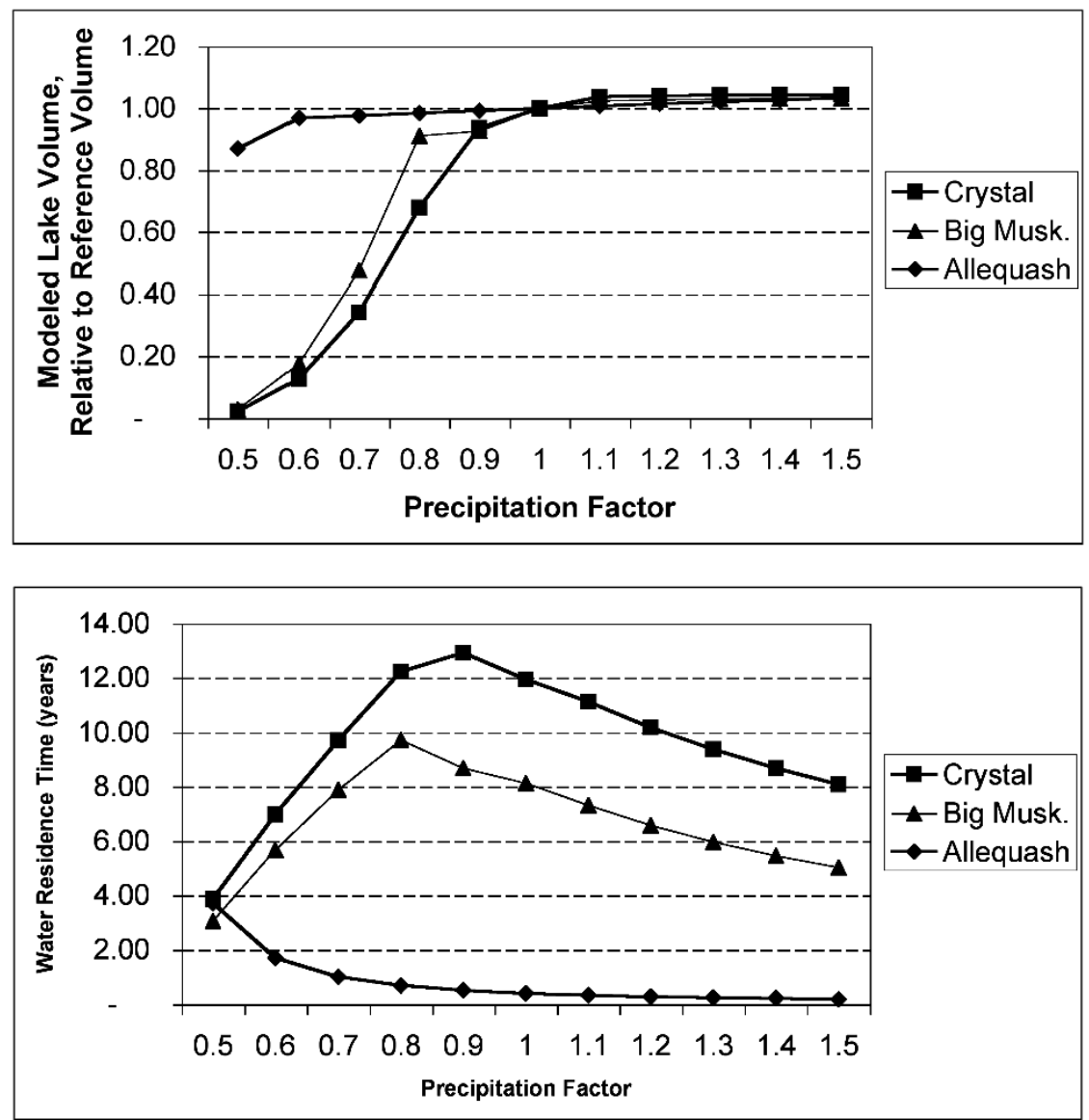

Figure 7. (top) Relative mean annual lake volume under scenarios of changing precipitation in representative lakes. (bottom) Sensitivity of modeled water residence time in scenarios of changing precipitation in representative lakes.

catchment than that for Crystal Lake, Big Muskellunge Lake persisted in the 0.9 and 0.8 scenarios but declined substantially in the 0.7 scenario. In contrast, Allequash Lake persisted in each of the drier climate scenarios, including those in which the lakes embedded in its catchment ceased to recharge the groundwater pool as their volume decreased. This difference across lake types is consistent with studies from other regions that found decreased sensitivity to climate fluctuations in drainage lakes (Street 1980), and agrees with observed records in the drought of the late 1980s in the NHLD, in which lake levels in the mounded and groundwater flowthrough lakes declined substantially by similar amounts, while little effect was seen on lake levels in Allequash (Webster et al. 1996).

Like the behavior of lake volume, modeled water residence time differed strongly by lake type in scenarios of increased or decreased precipitation (Figure 7 bottom). In increasingly wetter scenarios, WRT declined for all three lakes, since volume increased only slightly while outflow increased much more substantially. The behavior of the model was more complex in drier scenarios: for slightly drier 
scenarios in the mounded and groundwater flowthrough lakes when the steadystate lake volume was at or near its maximum (i.e., Crystal in the 0.9 scenario; Big Muskellunge in the 0.8 and 0.9 runs), WRT was modeled to be higher than the nominal case due to the reduced water flux of the system with an only slightly reduced volume. In the more extreme drying scenarios, as volume decreased substantially, WRT decreased for these lakes as lake volume dropped more quickly than the water flux from the lake. In Allequash, however, WRT increased in all drying scenarios; the large catchment area permitted the lake to persist, and its lake volume decreased relatively less than flux from the lake.

\subsubsection{Lake type and catchment-scale water balance}

With modeled precipitation changes, a different catchment-scale water balance could influence lake type by creating or drying a stream outflow. The whole landscape water budgets for Crystal, Big Muskellunge, and Allequash Lakes under scenarios of increased or decreased precipitation indicate that the mounded and groundwater flowthrough lakes process water similarly, while the drainage lake differs (Figure 8).

4.2.2.1. Drainage lake. For Allequash Lake, which has a stream outlet under current conditions, scenarios of increasing precipitation caused the streamflow to increase. In wetter scenarios, there was also an increase in the proportion of catchment precipitation leaving the system as streamflow. In contrast, in drier scenarios the relative importance of streamflow diminished, until in the most extreme precipitation scenario, Allequash became a groundwater flowthrough lake.

4.2.2.2. Mounded and groundwater flowthrough lakes. As in scenarios for the drainage lake, model results indicate that the mounded and groundwater flowthrough lakes could change type as the landscape-scale water balance changed. Water falling within the catchments of Crystal and Big Muskellunge Lakes has a similar fate under scenarios of increased or decreased precipitation; though they differ in morphometry and lake type, these two catchments routed water similarly in the model (Figure 8 top and middle). In these lakes, where today there are no stream outlets, a substantial long-term increase in precipitation could cause them to become drainage lakes, as their basins fill and the surplus water is converted to outflow. In wetter scenarios, modeled outflow increases not only in absolute terms but also relative to other components of the water balance; groundwater outflow and evapotranspiration also increase, though not as quickly as stream outflow. The primary effect of drier scenarios in these two lakes is a decrease in lake volume; because modeled lake area decreases rapidly with lake volume (Figure 5), lake evaporation decreases and the relative importance of evapotranspiration from the catchment increases (Figure 8).

\subsection{Generic lake model: Effect of variation in catchment size}

\subsubsection{Lake volume and water residence time}

In simulations holding lake size constant and varying the relative catchment area, lakes with little surrounding upland were more susceptible to water-level changes in changed climates, while lakes with a relatively large catchment were buffered from 

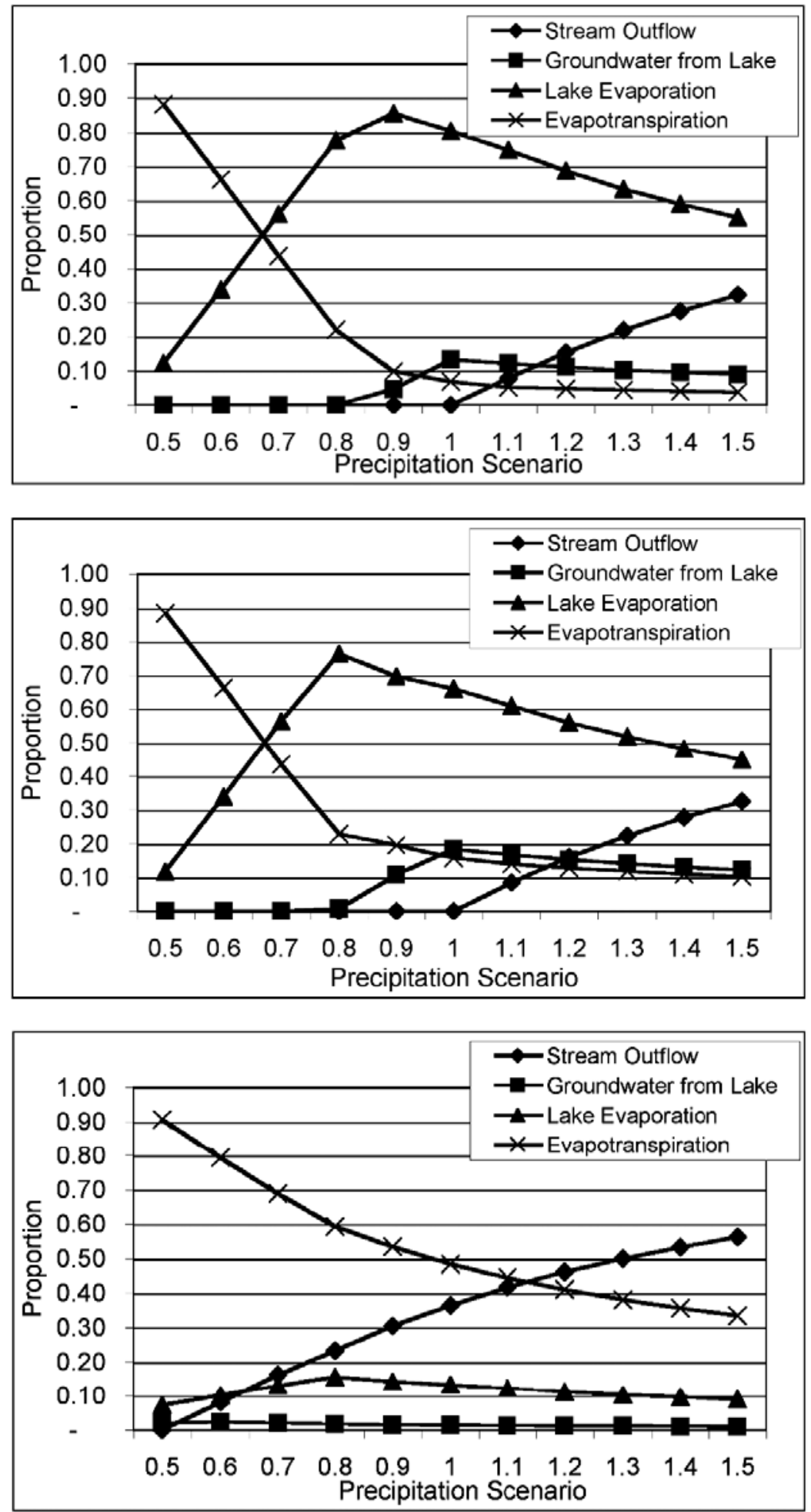

Figure 8. Catchment-scale water balance measures in scenarios of changing precipitation in three representative lakes: (top) Crystal, (middle) Big Muskellunge, and (bottom) Allequash. 

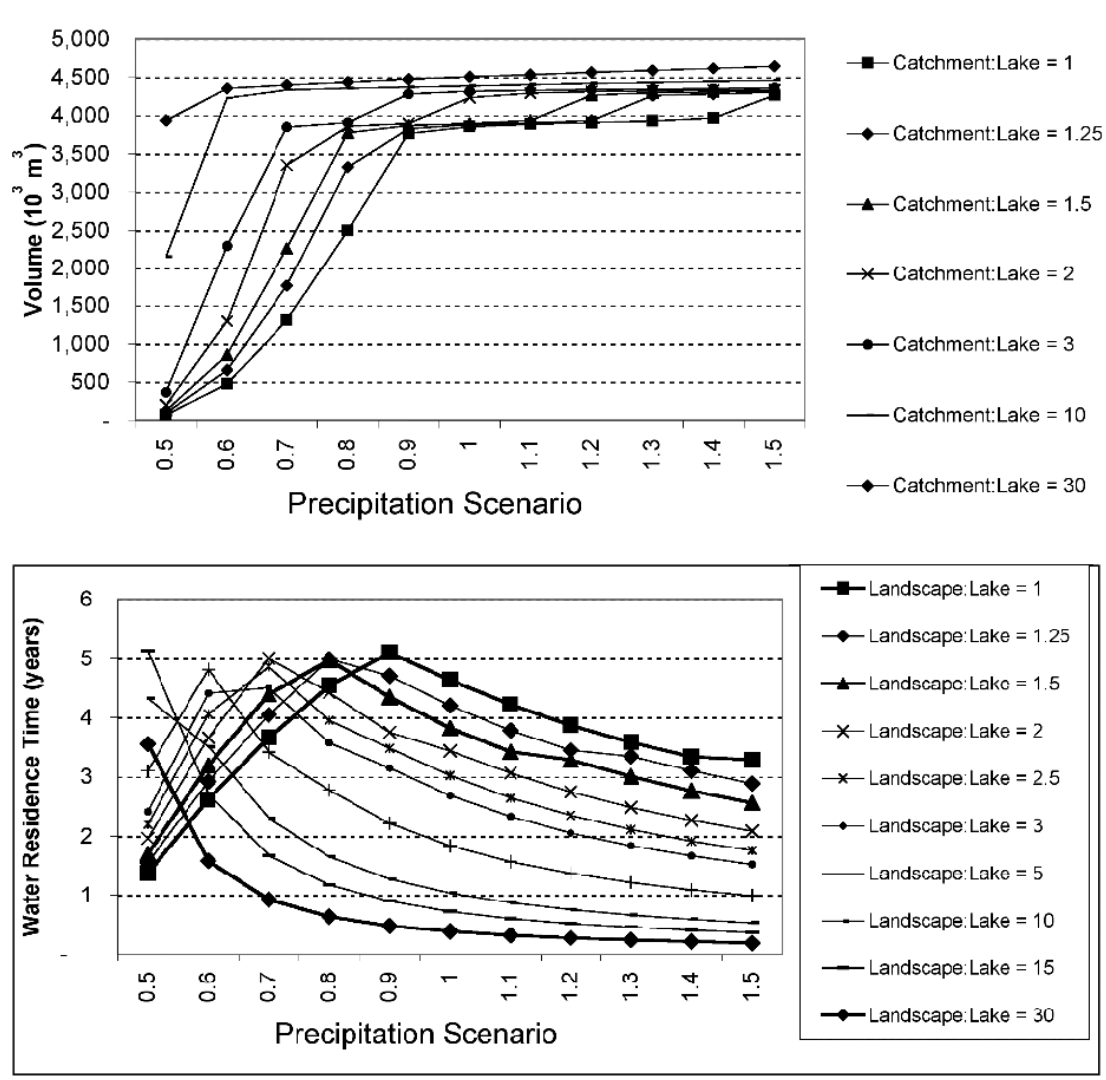

Figure 9. (†op) Sensitivity of modeled lake volume of a typical NHLD lake with groundwater catchments of different sizes under scenarios of changing precipitation. (bottom) Same as in (top), but for residence time.

water-level decrease in scenarios of less precipitation (Figure 9 top). Similarly, the impact of climate on water residence time was also dependent on the surrounding catchment size; thus, simulated lakes with more upland exhibited less sensitivity to variation in precipitation (Figure 9 bottom). Among lakes with the same volume and lake surface area, those with larger catchments had shorter water residence times, since lakes with larger catchments cycled more water through the lake.

A comparison of the modeled responses for the three example lakes (Figure 7) with simulations of a typical NHLD lake having a similar amount of surrounding upland (Figure 9) indicates that the catchment:lake ratio dominates the behavior of steady-state volume and water residence time in scenarios of increased or decreased precipitation. For example, the response curve of WRT for Crystal Lake when simulated with its specific characteristics (Figure 7) has a similar shape to that for a typical NHLD lake with a relative catchment size between 1 and 1.25 (Table 1; Figure 9 bottom). Across the wide range of lake sizes and shapes seen across the three lake types, this importance of relative catchment size is seen; the WRT response curves for Big Muskellunge and Allequash also closely resemble those for the typical NHLD lake with the appropriate relative catchment sizes $(1.36$ and 6.86 , respectively). Since these three lakes were used to calibrate the model, 
Table 4. Modeled catchment-scale water balance measures from a generic lake having the same catchment area:lake area (CA:LA) ratios seen in representative lakes.

\begin{tabular}{lccc}
\hline & $\begin{array}{c}\text { CA:LA }=1.1 \\
\text { (cf. Crystal) }\end{array}$ & $\begin{array}{c}\text { CA:LA }=1.36 \\
\text { (cf. Big Muskellunge) }\end{array}$ & $\begin{array}{c}\text { CA:LA }=6.86 \\
\text { (cf. Allequash) }\end{array}$ \\
\hline Evaporation & 0.77 & 0.63 & 0.13 \\
Groundwater flux from lake & 0.14 & 0.19 & 0.07 \\
Outflow & - & - & 0.31 \\
Evapotranspiration & 0.09 & 0.18 & 0.48 \\
\hline
\end{tabular}

the similarity between result calibration runs (which included lake shape) and these simulations (which generalize lake shape) indicates the relatively small influence of each lake's morphometry on such catchment-driven water balance measures.

The preeminence of catchment area and secondary influence of lake morphometry in these groundwater systems is consistent with results for Baltic lakes by Vassiljev (Vassiljev 1997; Vassiljev 1998), who found that the ratio of lake area to catchment area is the primary determinant of the response of lake level to precipitation changes in lakes having no groundwater flux. These results imply that the sensitivity of lake volume and water residence time to climate changes can be thought of along a continuum principally determined by the ratio of catchment size to the amount of open water in the catchment.

\subsubsection{Catchment-scale water balance: Effects of morphometry and relative catchment size}

The modeled catchment-scale water balance for the three representative lakes with lake shape included (Table 3) is nearly indistinguishable from results for a lake of generic size having the corresponding catchment:lake ratio (Table 4). More generally, the set of simulations systematically varying catchment area while

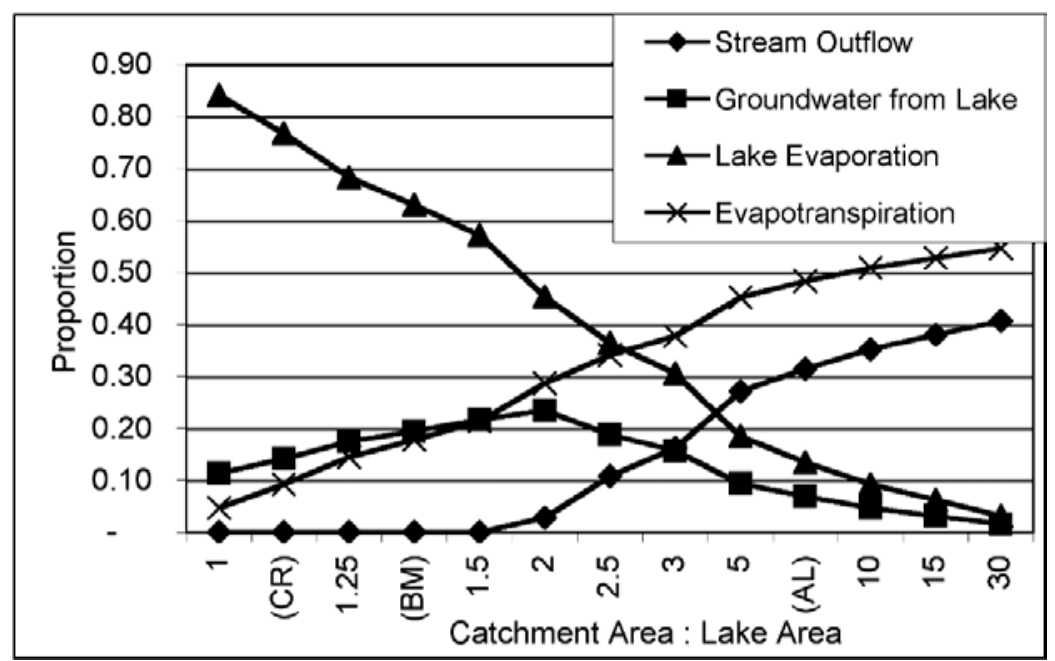

Figure 10. Catchment-scale water balance measures in a typical NHLD lake with groundwater catchments of different sizes. 
holding lake morphometry constant suggests that the fate of precipitation in a lake's catchment can be largely understood along a continuum of the catchment:lake ratio (Figure 10). In simulations for lakes with a larger relative catchment size, about half of the precipitation in the catchment is returned to the atmosphere through evapotranspiration; the role of ET drops substantially in lakes surrounded by only a small amount of land. In those lakes, evaporation from the lake surface can account for around $80 \%$ of the catchment water budget, with the remainder of the catchment's precipitation leaving the system via evapotranspiration and downgradient seepage from the lake.

When the modeled catchment-scale water balance measures for representative lakes are considered, they also orient along the catchment:lake continuum (Figure 10). That is, for Big Muskellunge and Allequash Lakes, it is important to consider that there are nested lake catchments within their groundwater catchment boundaries. Evaporation from within the entire Allequash catchment, for example, occurs from the lake surfaces of Crystal, Big Muskellunge, and Allequash Lakes, for a total of 512 ha of lake area (Table 1); in that case, the ratio of catchment area to lake area is $3513: 512=6.86$. When the resulting water balance parameters are plotted using this value for the catchment:lake area (Figure 10), the results for Allequash Lake show that water balance results are driven by the open water in its catchment, are not strongly affected by lake morphometry, and situate well along the continuum of relative catchment size.

\section{Discussion and conclusions}

This generic water balance model is designed as a prototype for a spatially explicit catchment-based model-integrating terrestrial and aquatic processes for the Northern Highland Lake District (NHLD). In the NHLD, much is known about a few very well studied lakes, three of which were chosen as the representative lakes for this study. For many others, however, little more than the lake's surface area is known. As a result, this model was designed to use as few parameters as necessary to explore the key drivers of lake hydrologic type and the fate of precipitation falling within a lake's catchment. In this complex landscape, a relatively small set of drivers can adequately represent basic facts about the water balance in lakes of dramatically different sizes, shapes, and types.

In this simple model, results suggest that long-term changes in the precipitation regime can affect lake type, changing, for example, a groundwater flowthrough lake to a drainage lake. Lakes with relatively small catchment areas (e.g., Crystal and Big Muskellunge) are more responsive to hydrologic changes, given their susceptibility to decreases in volume in drying scenarios. Lakes with a relatively large catchment (e.g., Allequash), in contrast, are buffered against large decreases in volume or changes in lake water residence time.

Although these representative lakes span several orders of magnitude for measures of catchment area, lake area, and lake volume, with depth ratio values that vary widely, lake morphometry plays a limited role in determining the fate of water at the catchment scale. Instead, results from runs in a generic lake suggest that even in groundwater-dominated systems, relative catchment area is the primary influence on the ultimate fate of water in a given lake's catchment; thus, lake catchment size and lake area are sufficient to infer the likely lake type and a 
wide range of water balance measures for the catchment. In lakes surrounded by very little land (CA:LA between 1 and 2), most of the water entering the catchment (primarily through precipitation) is evaporated, with most of the rest routed to groundwater flow from the lake. As a result, we would expect that most lakes of the NHLD having this range of relative catchment size values would be, like Crystal and Big Muskellunge, lakes without a stream outlet under current climate conditions. Drainage lakes in the NHLD are likely to be surrounded by upland at least as large as the lake area itself (i.e., CA:LA $\geq 2$ ). Above this threshold, groundwater flow from the lake is too slow for the entire surplus to leave the system via seepage, evaporation, and evapotranspiration. For lakes surrounded by larger amounts of upland, the model suggests that streamflow is likely and that it increases dramatically with increasing relative catchment size.

The relatively simple approach of the model, while appealing, does suggest several cautions regarding its extension to the entire NHLD. First, the rest of the region has been studied less closely than the representative lakes here, and as a result it is unlikely that both surface and subsurface flow patterns can be known a priori. This difficulty, particularly in estimating groundwater catchments, could substantially complicate analyses in other areas. Additionally, there may be multiple ways in which a set of lakes could be connected yet demonstrate the same water balance measures; these different solutions could imply dramatically different biogeochemistry. Similarly, our conclusions about the relative unimportance of lake shape and size on catchment-scale water balance measures does not suggest that morphometry is also unimportant for biogeochemical cycling; in fact, multiple studies have shown the influence of lake morphometry on lake chemistry (Fee et al. 1994; Fee et al. 1992; M. Genkai-Kato and S. R. Carpenter 2003, unpublished manuscript; Morales-Baquero et al. 1999; Riera et al. 2000).

Despite these caveats, opportunities exist for scaling some water balance measures between lakes of different sizes using their surface area and relative catchment size. Using a suite of model results for a lake of typical size and shape appears to be a straightforward way to accurately estimate, for example, the water residence time for a lake with a known surface area and relative catchment area in the NHLD. Although the nesting of lakes is important to representing the timing of flows among pools and out of the catchment, the combined surface area of the nested lakes (to appropriately estimate evaporation) appears to be sufficient for understanding the relative magnitude of the outputs of water from the catchment.

Results from simulating a lake of typical size and shape suggest that the large differences in water balance measures for different lake types in the NHLD can be understood as occurring along a continuum of relative catchment size. This suggests that for the many lakes in the NHLD for which mean depth (and thus depth ratio and volume) is not known, modeled water balance results derived from a typical NHLD lake may be able to form a basis for representing water balance drivers of biogeochemical cycling in and through groundwater catchments across the entire region. A modest amount of information about lakes and their catchments may be sufficient for gaining a substantial increase in our understanding of the integrated aquatic-terrestrial landscape of the NHLD. 
Acknowledgments. Chris Kucharik assisted with recent developments in IBIS and provided technical help with model runs. John Lenters, Tim Kratz, Monica Turner, and Steve Carpenter provided extremely useful detailed comments on earlier versions of the manuscript. This work was funded by the Mellon Foundation.

\section{References}

Baines, S. B., K. E. Webster, T. K. Kratz, S. R. Carpenter, and J. J. Magnuson, 2000: Synchronous behavior of temperature, calcium, and chlorophyll in lakes of northern Wisconsin. Ecology, 81, 815-825.

Benson, B., cited 2003: Lake bathymetry. Center for Limnology, University of WisconsinMadison, North Temperate Lakes Long-Term Ecological Research Program. [Available online at http://lter.limnology.wisc.edu.]

—, and M. D. Mackenzie, 1995: Effects of sensor spatial-resolution on landscape structure parameters. Landscape Ecol., 10, 113-120.

, J. D. Lenters, J. J. Magnuson, M. Stubbs, T. K. Kratz, P. J. Dillon, R. E. Hecky, and R. C. Lathrop, 2000: Regional coherence of climatic and lake thermal variables of four lake districts in the Upper Great Lakes Region of North America. Freshwater Biol., 43, 517-527.

Bullen, T. D., D. P. Krabbenhoft, and C. Kendall, 1996: Kinetic and mineralogic controls on the evolution of groundwater chemistry and $\mathrm{Sr}-87 / \mathrm{Sr}-86$ in a sandy silicate aquifer, northern Wisconsin, USA. Geochimica Cosmochimica Acta, 60, 1807-1821.

Bureau of Water Resources Management and Bureau of Fisheries Management, 2001: Wisconsin Lakes. Pub-FH-800, Wisconsin Department of Natural Resources (DNR), Madison, WI, $178 \mathrm{pp}$.

Carpenter, S. R., 1983: Lake geometry-Implications for production and sediment accretion rates. J. Theor. Biol., 105, 273-286.

Champion, G., 1998: Transient and steady-state flow models of a ground-water and lake system: Trout Lake Basin, northern Wisconsin. University of Wisconsin-Madison, M.S. thesis, $109 \mathrm{pp}$.

Chipman, J. W., T. M. Lillesand, J. E. Schmaltz, J. E. Leale, and M. J. Nordheim, 2004: Mapping lake water clarity with Landsat images in Wisconsin, USA. Can. J. Remote Sens 30, 1-7.

Christensen, D. L., and Coauthors, 1996: Pelagic responses to changes in dissolved organic carbon following division of a seepage lake. Limnol. Oceanogr., 41, 553-559.

Coe, M. T., 1998: A linked global model of terrestrial hydrologic processes: Simulation of modern rivers, lakes, and wetlands. J. Geophys. Res., 103 (D8), 8885-8899.

Cole, J. J., 1999: Aquatic microbiology for ecosystem scientists: New and recycled paradigms in ecological microbiology. Ecosystems, 2, 215-225.

Dearing, J., and I. Foster, 1986: Lake sediments and palaeohydrological studies. Handbook of Holocene Palaeoecology and Palaeohydrology, B. E. Berglund, Ed., J. Wiley and Sons, 67-90.

Dripps, W. R., 2003: The spatial and temporal variability of groundwater recharge within the Trout Lake Basin of northern Wisconsin. Ph.D. thesis, University of WisconsinMadison, Madison, WI, $250 \mathrm{pp}$.

Elder, J. F., N. B. Rybicki, V. Carter, and V. Weintraub, 2000: Sources and yields of dissolved carbon in northern Wisconsin stream catchments with differing amounts of peatland. Wetlands, 20, 113-125. 
Fee, E. J., J. A. Shearer, E. R. Debruyn, and E. U. Schindler, 1992: Effects of lake size on phytoplankton photosynthesis. Can. J. Fish. Aquatic Sci., 49, 2445-2459.

- , R. E. Hecky, G. W. Regehr, L. L. Hendzel, and P. Wilkinson, 1994: Effects of lake size on nutrient availability in the mixed-layer during summer stratification. Can. J. Fish. Aquatic Sci., 51, 2756-2768.

Foley, J. A., and Coauthors, 1996: An integrated biosphere model of land surface processes, terrestrial carbon balance, and vegetation dynamics. Global Biogeochem. Cycles, 10, 603-628.

Gergel, S. E., M. G. Turner, and T. K. Kratz, 1999: Dissolved organic carbon as an indicator of the scale of watershed influence on lakes and rivers. Ecol. Appl., 9, 1377-1390.

Harrison, S. P., G. Yu, and P. E. Tarasov, 1996: Late quaternary lake-level record from northern Eurasia. Quat. Res., 45, 138-159.

Hostetler, S. W., G. T. Bates, and F. Giorgi, 1993: Interactive coupling of a lake thermalmodel with a regional climate model. J. Geophys. Res., 98 (D3), 5045-5057.

Hunt, R. J., M. P. Anderson, and V. A. Kelson, 1998: Improving a complex finite-difference ground water flow model through the use of an analytic element screening model. Ground Water, 36, 1011-1017.

Hurley, J. P., D. E. Armstrong, G. J. Kenoyer, and C. J. Bowser, 1985: Ground-water as a silica source for diatom production in a precipitation-dominated lake. Science, 227, 15761578.

Kim, K., M. P. Anderson, and C. J. Bowser, 1999: Model calibration with multiple targets: A case study. Ground Water, 37, 345-351.

Kling, G. W., G. W. Kipphut, M. M. Miller, and W. J. O’Brien, 2000: Integration of lakes and streams in a landscape perspective: The importance of material processing on spatial patterns and temporal coherence. Freshwater Biol., 43, 477-497.

Krabbenhoft, D. P., J. M. Benoit, C. L. Babiarz, J. P. Hurley, and A. W. Andren, 1995: Mercury cycling in the Allequash Creek watershed, northern Wisconsin. Water Air Soil Pollut., 80, 425-433.

Kratz, T. K., K. E. Webster, C. J. Bowser, J. J. Magnuson, and B. J. Benson, 1997: The influence of landscape position on lakes in northern Wisconsin. Freshwater Biol., 37, 209-217.

Kucharik, C. J., and Coauthors, 2000: Testing the performance of a Dynamic Global Ecosystem Model: Water balance, carbon balance, and vegetation structure. Global Biogeochem. Cycles, 14, 795-825.

Likens, G. E., 1985: An Ecosystem Approach to Aquatic Ecology: Mirror Lake and Its Environments. Springer-Verlag, 516 pp.

Magnuson, J. J., T. K. Kratz, and B. B. Benson, Eds., 2004: Long-Term Ecological Research of North Temperate Lakes: Dynamics of Lakes in the Landscape. Oxford Press, in press.

Magny, M., 1992: Holocene lake-level fluctuations in Jura and the northern sub-Alpine ranges, France-Regional pattern and climatic implications. Boreas, 21, 319-334.

Miller, J. R., G. L. Russell, and G. Caliri, 1994: Continental-scale river flow in climate models. J. Climate, 7, 914-928.

Morales-Baquero, R., R. Carrillo, I. Reche, and P. Sanchez-Castillo, 1999: Nitrogenphosphorus relationship in high mountain lakes: Effects of the size of catchment basins. Can. J. Fish. Aquatic Sci., 56, 1809-1817.

New, M., M. Hulme, and P. Jones, 2000: Representing twentieth-century space-time climate variability. Part II: Development of 1901-96 monthly grids of terrestrial surface climate. J. Climate, 13, 2217-2238. 
Pint, C. D., 2002: A groundwater flow model of the Trout Lake Basin: Calibration and lake capture zone analysis. M.S. thesis, University of Wisconsin-Madison, $123 \mathrm{pp}$.

Riera, J. L., J. J. Magnuson, T. K. Kratz, and K. E. Webster, 2000: A geomorphic template for the analysis of lake districts applied to the Northern Highland Lake District, Wisconsin, USA. Freshwater Biol., 43, 301-318.

Soranno, P. A., and Coauthors, 1999: Spatial variation among lakes within landscapes: Ecological organization along lake chains. Ecosystems, 2, 395-410.

Street, F. A., 1980: The relative importance of climate and local hydrogeological factors in influencing lake-level fluctuations. Palaeoecol. Afr., 12, 137-158.

- and A. T. Grove, 1976: Environmental and climatic implications of late quaternary lake-level fluctuations in Africa. Nature, 261, 385-390.

, and R. A. Perrott, 1993: Holocene vegetation, lake levels, and climate of Africa. Global Climates since the Last Glacial Maximum, H. E. Wright et al., Eds., University of Minnesota Press, 318-356.

Vassiljev, J., 1997: Simulating the palaeorecord of northern European lakes using a coupled lake-catchment model. Lund University, Lund, Sweden, 19 pp. , 1998: The simulated response of lakes to changes in annual and seasonal precipitation: Implication for Holocene lake level changes in northern Europe. Climate Dyn., 14, 791801.

Walker, J. F., and D. P. Krabbenhoft, 1998: Groundwater and surface-water interactions in riparian and lake-dominated systems. Isotope Tracers in Catchment Hydrology, C. Kendall and J. J. McDonnell, Eds., Elsevier, 467-488.

Webster, K. E., T. K. Kratz, C. J. Bowser, J. J. Magnuson, and W. J. Rose, 1996: The influence of landscape position on lake chemical responses to drought in northern Wisconsin. Limnol. Oceanogr., 41, 977-984.

— chemical responses to drought. Freshwater Biol., 43, 499-515.

Wetzel, R. G., 2001: Limnology: Lake and River Ecosystems. Academic Press, 1006 pp.

Winter, T. C., J. W. Harvey, O. L. Franke, and W. M. Alley, 1998: Ground water and surface water: A single resource. USGS Circular 1139, U.S. Dept. of the Interior, Denver, CO, 79 pp.

Yu, G. E., and S. P. Harrison, 1995: Holocene changes in atmospheric circulation patterns as shown by lake status changes in Northern Europe. Boreas, 24, 260-268.

Earth Interactions is published jointly by the American Meteorological Society, the American Geophysical Union, and the Association of American Geographers. Permission to use figures, tables, and brief excerpts from this journal in scientific and educational works it hereby granted provided that the source is acknowledged. Any use of material in this journal that is determined to be "fair use" under Section 107 or that satisfies the conditions specified in Section 108 of the U.S. Copyright Law (17 USC, as revised by P.IL. 94553) does not require the publishers' permission. For permission for any other form of copying, contact one of the copublishing societies. 